\author{
Małgorzata Baran \\ Collegium Civitas, Warszawa \\ Monika Kłos \\ Wyższa Szkoła Biznesu w Pile \\ Jacek Strojny \\ Politechnika Rzeszowska
}

\title{
Kreowanie zachowań przedsiębiorczych w procesie zarządzania zespołem projektowym na przykładzie uczelni wyższej
}

\author{
Creating entrepreneurial behavior in the management of the project team \\ on the example of a university
}

\begin{abstract}
Streszczenie
W artykule przedstawiono analizę kompetencji projektowych jako stymulantów efektywnego zarządzania projektem. Przyjęto jednocześnie, że wprowadzenie orientacji projektowej może być traktowane jako jeden z przykładów intraprzedsiębiorczości. Może także służyć do kreowania zachowań przedsiębiorczych w firmie, sprzyjając budowaniu kultury organizacyjnej pozwalającej na wprowadzanie zmian, nawet tych o charakterze innowacyjnym. Wykorzystanie potencjału osób przedsiębiorczych umożliwia osiąganie sukcesów podejmowanych działań projektowych. Muszą one być jednak wspierane określonymi parametrami (cechami) organizacji. Orientacja projektowa jest takim sposobem zarządzania, który tworzy środowisko sprzyjające przedsiębiorczości. Obejmuje szereg działań motywacyjnych, ale ma także charakter systemowy, gdyż dostarcza odpowiednich technik zarządzania, a nawet instrumentów w postaci oprogramowania komputerowego.

Podstawą analiz prowadzonych w niniejszym artykule jest badanie poziomu orientacji (dojrzałości) projektowej przeprowadzone w jednej z warszawskich uczelni wyższych z wykorzystaniem metodyki Pro-Five. Ze względu na tematykę artykułu prezentuje się jeden spośród pięciu wymiarów analizy, a więc zarządzanie zespołem projektowym. Pozostałe wymiary analizy to: kultura projektowa, zarządzanie strategiczne, zarządzanie projektami oraz kompleksowe podejście do zarządzania projektami. W ramach wybranego wymiaru analizuje się pięć parametrów szczegółowych: rozwój kompetencji projektowych, kierownika projektu, zespół projektowy, komunikację w zespole i motywację projektową. Analiza tych parametrów stanowi podstawę oceny możliwości kreowania zachowań przedsiębiorczych w uczelni przez wdrożenie orientacji projektowej.
\end{abstract}

\footnotetext{
Abstract

In this paper the authors present an analysis of project competences as stimuli of effective project management. However, they find that the introduction of a project orientation can be considered as one of the examples of entrepreneurship. It can be also used to create entrepreneurial behavior within a company, simultaneously promoting the building of organizational culture that support making changes, even those innovative. Using the potential of entrepreneurs can be succeed by project activities. As a matter of fact, they need to be supported by certain parameters (attributes) of the enterprise. Further, it is worth to emphasize that the project management orientation is the kind of management, which creates business environment. It includes both a number of motivation factors,
} 
but it has also a system nature, providing the appropriate management techniques and even the computer software instruments.

The aim of the analysis conducted in this paper is to study the orientation level (maturity) project conducted in one of the Warsaw's universities using the methodology Pro-Five. Due to the subject matter of the article one of the five dimensions of analysis, so the management of the project team. Others include design culture, strategic management, project management, and comprehensive approach to project management. The selected dimension examines five specific parameters: competence development project, a project manager, a project team, communication of a team and motivation of a design. It is their analysis that forms the basis for assessment of the potential creation of entrepreneurial behavior in schools with guidance through the implementation of a project.

Słowa kluczowe: dojrzałość projektowa; kompetencje projektowe; postawy przedsiębiorcze; zarządzanie zespołem projektowym

Key words: competence of project; entrepreneurial attitudes; maturity of project; management of the project team

\section{Wprowadzenie}

Skuteczna realizacja zadań, w tym coraz częściej projektów, decyduje o sukcesie organizacji działających we współczesnej, dynamicznej gospodarce. Tymczasem na przebieg projektów wpływa wiele czynników endo- i egzogennych. Pierwsze z nich odnoszą się do cech organizacji realizującej projekt, które to cechy składają się na tzw. orientację projektową. Czynniki zewnętrzne z kolei determinują przebieg projektu, tworząc szanse lub zagrożenia.

Oczywiście dynamika otoczenia wymusza podnoszenie kompetencji w zakresie zarządzania projektami i przyjmuje niekiedy charakter systemowy określany jako orientacja projektowa. Dzięki jej wdrożeniu zyskuje się instrumenty (techniki zarządzania, oprogramowanie, zmiany kulturowe), zapewniające podniesienie efektywności i skuteczności reakcji na zmianę w otoczeniu. W coraz większym stopniu te spostrzeżenia odnoszą się także do sektora naukowego, w tym uczelni. Mówi się o różnych koncepcjach ich funkcjonowania, które można sprowadzić do modeli uniwersytetu przedsiębiorczego czy uniwersytetu trzeciej generacji. W każdej z nich zauważyć można połączenie dwóch istotnych zjawisk - przedsiębiorczości (akademickiej, intraprzedsiębiorczości) z koniecznością zarządzania projektami badawczymi czy komercjalizacyjnymi. Autorzy ninejszego artykułu stoją na stanowisku, że oba te zjawiska należy traktować jako komplementarne. Zmiany, przed którymi stoją polskie uczelnie, wymuszać więc będą zarówno wdrażanie podejścia projektowego w wymiarze instytucjonalnym, jak i zmiany postaw pracowników na bardziej aktywne - przedsiębiorcze.

Metody oceny orientacji projektowej mogą być na tym tle ramami odniesienia względem definiowania, doskonalenia i weryfikowania wiedzy, umiejętności i postaw profesjonalnej kadry kierowników projektów także w polskich uczelniach wyższych. Analizując poziom dojrzałości projektowej pewnej uczelni wyższej, autorzy artykułu za cel postawili sobie ocenę możliwości wykorzystania orientacji projektowej do kreowania postaw przedsiębiorczych. Ocenę tę poprzedza autorska próba sprawdzenia zależności między kompetencjami w ogóle, kompetencjami przedsiębiorczymi i postawami przedsiębiorczymi a sprawnością funkcjonowania zespołu projektowego.

\section{Istota kompetencji projektowych}

Pojęcie kompetencja wywodzi się od łac. słowa competentia, co tłumaczy się jako 'odpowiedzialność, przydatność' (Borowski, Dryla, Kanarski, Rokicki, 2001: 59). W zarządzaniu 
funkcjonuje wiele definicji kompetencji, zarówno pełnych, jak i ukierunkowanych. Według C. Levy-Leboyer'a (1997: 19), kompetencje dotyczą zintegrowanego wykorzystania zdolności, cech osobowości, a także nabytej wiedzy i umiejętności w celu doprowadzenia do pomyślnego wykonania złożonej misji w ramach przedsiębiorstwa. Z kolei R. Boyatzis (1982: s. 12) postrzega kompetencję jako zbiór charakterystyk indywidualnych, które należą do tak odmiennych dziedzin, jak zdolności, motywy, cechy osobowości, predyspozycje czy obraz samego siebie i swojej roli społecznej, lub stanowią zbiór nabytej wiedzy. Bogatą definicję kompetencji zaprezentował T. Rostkowski (2003: 165) w artykule Zintegrowane systemy zarzadzania kompetencjami. Uważa on, że kompetencje to: wiedza, umiejętności, uzdolnienia, style działania, osobowość, wyznawane zasady, zainteresowania i inne cechy, które używane i rozwijane w procesie pracy prowadzą do rezultatów zgodnych ze strategicznymi zamierzeniami przedsiębiorstwa. T. Oleksyn (2001: 16) definiuje natomiast kompetencje jako zakres wiedzy, umiejętności, doświadczenia, postaw i zachowań oraz innych cech psychofizycznych ważnych w danej pracy, gotowość pracownika do działania w danych warunkach i zdolność przystosowania do zmian, a także formalne wyposażenie w możliwości działania i podejmowania decyzji związanych z pracą.

Dla definicji kompetencji można sformułować elementy wspólne wynikające wprost lub pośrednio z tych stwierdzeń:

- kompetencje to cechy przynależne indywidualnym osobom (łączy ze sobą cechy osobowości i umiejętności wyuczone),

- kompetencje są nierozerwalnie związane z miejscem pracy (tj. stanowiskiem i wykonywanymi zadaniami),

- wysoki poziom kompetencji pozwala na skuteczną realizację zadań,

- zbiór cech składających się na kompetencje jest obszerny i różnorodny,

- istotna jest wymierność kompetencji (dzięki niej można stworzyć profil każdego stanowiska). Kompetencje projektowe to zatem zbiór cech pracowników, pozwalających na skuteczną i efektywną realizację zadań organizacji, a w szczególności podejmowanych przez nią przedsięwzięć projektowych. Tego typu kompetencje można analizować przynajmniej w kilku płaszczyznach, w zależności od przyjętego podejścia. W jednym z nich, prezentowanym przez organizację IPMA ${ }^{1}$, wyróżnia się trzy rodzaje kompetencji (Dałkowski i in., 2009):

- kompetencje behawioralne,

- kompetencje techniczne,

- kompetencje kontekstowe.

Pierwsza grupa kompetencji wiąże się z umiejętnością budowania odpowiednich relacji z innymi członkami organizacji oraz podmiotami zewnętrznymi w związku z realizacją powierzonych zadań. Chodzi tutaj zarówno o zdolności komunikacyjne, umiejętność pracy w grupie, jak i o kompetencje przywódcze, niezbędne często kierownikom projektów. Bardzo ważnym elementem tych kompetencji jest także orientacja na wyniki. Umiejętności techniczne odnoszą się z kolei do znajomości technik zarządzania oraz narzędzi (np. programów komputerowych). Ostatnia grupa kompetencji wiąże się natomiast $\mathrm{z}$ umiejętnością rozumienia organizacyjnego otoczenia projektu, a więc procesu zarządzania realizowanego w nieco bardziej ogólnym wymiarze.

Przyjęta w niniejszym badaniu metodyka Pro-Five odwołuje się oczywiście do podejścia IPMA i innych znanych w świecie metodyk (PMI czy PRINCE2). Jest jednak autorska, gdyż stanowi odpowiednio przygotowany, na podstawie doświadczenia z różnego typu organizacja-

\footnotetext{
${ }^{1}$ International Project Management Association - jedna z największych organizacji międzynarodowych zajmujących się promowaniem metody zarządzania projektami.
} 
mi, zestaw kompetencji projektowych. Szczegółowa ich analiza została przedstawiona w dalszej części artykułu, przy prezentacji wyników badań.

\section{Kompetencje projektowe versus kompetencje przedsiębiorcze}

Wśród wielu rodzajów kompetencji warto wskazać podział kompetencji, który daje możliwość określenia kompetencji przedsiębiorczych, czyli tych wynikających z cech wrodzonych i osobowości. L. Spencer i S. Spencer (1993) zbadali kompetencje indywidualne. Ustalili, że w ich skład wchodzą następujące elementy: wiedza, umiejętności, wartości i standardy, motywy, etyka pracy, entuzjazm oraz własny wizerunek. Kompetencje indywidualne to cechy człowieka - wrodzone oraz nabyte. Do pierwszej grupy zaliczyć można cechy psychofizyczne i osobowościowe oraz zdolności. Do grupy cech nabytych zalicza się natomiast kwalifikacje zawodowe i ponadzawodowe, umiejętności, doświadczenie oraz zainteresowania. Cechy wrodzone można wyćwiczyć, lecz bardzo trudno je w sobie wykształcić.

S. Konarski i D. Turek wskazują inne rodzaje kompetencji. Są to kompetencje: poznawcze, emocjonalne, społeczne, językowe, komunikacyjne, numeryczne, wolitywne, interpretacyjne, temporalne, autokreatywne, zawodowe, biograficzne, retrospektywne i pragmatyczne, twórcze, etyczne, międzykulturalne i globalne (Markowski, 2008). Wybrane w artykule typologie kompetencji pozwalają uzyskać konsensus co do wskazań kompetencji przedsiębiorczych.

W literaturze przedmiotu przedsiębiorczość definiowana jest w dwojaki sposób: jako zbiór cech osoby przedsiębiorczej oraz jako proces, czyli sposób podejmowania działań osób przedsiębiorczych. Pierwsze podejście odpowiada na pytanie, jakimi cechami powinna charakteryzować się osoba przedsiębiorcza, drugie zaś mówi o tym, jakie działania musi ona podjąć, aby osiągnąć zamierzone cele. Z tego też względu definicje opisujące i analizujące przedsiębiorczość można podzielić wg kryteriów uwzględniających (Piasecki, 1997; Antoszkiewicz, 2003):

1. cechy osobowe przedsiębiorcy, spośród których najczęściej wymieniane to: kreatywność, potrzeba osiągnięć, skłonność do ryzyka (podejście psychologiczne) oraz uwarunkowania społeczne, rodzinne, edukacyjne, wyznaniowe (podejście socjologiczne);

2. działania przedsiębiorcze oparte na ocenie ekonomicznej szans podejmowanego działania, m.in. uruchomienie i rozwój danego przedsięwzięcia, możliwości uzyskania oczekiwanego efektu, oszacowanie zagrożeń i ryzyka danego przedsięwzięcia oraz jego innowacyjności;

3. zachowania kierownicze, rozróżniane w zależności od pracy indywidualnej czy osób działających w zorganizowanych systemach.

Analiza przedsiębiorczości - cech i postaw z nią związanych - wskazuje na wielowymiarowość tego zjawiska. Wykorzystanie potencjału cech osób przedsiębiorczych umożliwia osiąganie sukcesów podejmowanych działań projektowych, jednak inicjatywy przedsiębiorcze muszą być wspierane określonymi warunkami politycznymi, instytucjonalnymi i społecznymi ${ }^{2}$. Możliwość kształtowania postaw przedsiębiorczych przez odpowiednie działania organizacyjne wewnętrzne, np. działania motywacji finansowej i niefinansowej, zwiększa liczbę osób podejmujących działania innowacyjne korzystne dla przedsiębiorstwa. Cechy osoby przedsiębiorczej odnoszą się do

\footnotetext{
2 Polska Konfederacja Pracodawców Prywatnych Lewiatan w stworzonym przez siebie programie gospodarczym do grupy czynników sprzyjających rozwojowi przedsiębiorczości zaliczyła m.in.: obniżenie pozapłacowych kosztów pracy, samozatrudnienie, reformę systemu regulacji, dokończenie prywatyzacji, ograniczenie do minimum liczby koncesji i zezwoleń na prowadzenie działalności gospodarczej, reprywatyzację służącą uregulowaniu stosunków własnościowych, reformę sądownictwa gospodarczego, reformę edukacji osób dorosłych (Program gospodarczy Lewiatana szansą dla rozwoju (2007). Rzeczpospolita, 110, B2).
} 
jednostki ludzkiej - są to charakterystyczne dla niej zachowania, niezbędne do dostrzeżenia i wykorzystania pojawiających się okazji. Należą do nich (Stoner i in., 2001; Gruszecki, 1994):

- duża potrzeba osiągnięć wraz ze zdolnością i gotowością do przejmowania inicjatywy,

- wewnętrzne umiejscowienie kontroli nad własnym życiem,

- skłonność do podejmowania działań w określonych granicach ryzyka oraz tolerowanie niepewności w podejmowaniu decyzji,

- dążenie do szybkiej realizacji zadań przez branie na siebie większych obowiązków powodujących długotrwały wysiłek,

- zdolność rozumienia potrzeb rynku, umiejętność ich prognozowania, a nawet wyprzedzania,

- kojarzenie informacji z różnorodnych dziedzin w obszarze podejmowanych działań,

- zdolność kierowania ludźmi w określonych strukturach formalnych, budzenie u pracowników entuzjazmu i zaufania.

Warto podkreślić, że istnieje duża zbieżność pomiędzy kompetencjami potrzebnymi z punktu widzenia przedsiębiorczości oraz tymi wskazywanymi jako niezbędne dla skutecznego zarządzania projektami. Przykładowy zestaw zachowań przedsiębiorczych i kompetencji projektowych przedstawiono w tabeli 1 .

\section{Wybrane elementy orientacji projektowej}

Zarówno kompetencje projektowe, jak i kompetencje przedsiębiorcze muszą być analizowane w kontekście otoczenia wewnętrznego, w którym są kształtowane. Organizacja zorientowana projektowo to taka, która potrafi stworzyć środowisko sprzyjające efektywnej realizacji przedsięwzięć. W organizacjach zorientowanych na projekty, gdzie udział zadań realizowanych przez interdyscyplinarne zespoły jest duży, powodzenie projektu zależy w dużej mierze od kompetencji wpływających na sprawność zespołu projektowego. Stąd też, badając orientację projektową, należy zwracać uwagę na doświadczenia pracowników w realizacji projektów oraz zdolności do zajmowania przez nich określonych pozycji w zespole projektowym. W tej analizie warto zwrócić szczególną uwagę na: mechanizmy przewodzenia, jakość komunikacji oraz motywację projektową.

\section{Rola kierownika projektu}

Projekt to doskonały przykład aktywności biznesowej, w której warunkiem koniecznym zarówno dla kierownika, jak i dla zespołu jest wykorzystywanie tak zaplanowanych narzędzi zarządzania, aby umożliwiały one monitorowanie osiągania założonych wskaźników. Kieronicy projektów muszą bezdyskusyjnie mieć umiejętności przywódcze, stanowiące bardzo ważne uzupełnienie metodyk zarządzania projektami. Nie wystarczy bowiem opracować procedurę zarządzania komunikacją i operacyjnie ją wykorzystywać, trzeba zorganizować swój zespół wokół celów i powodować, aby każdy z członków miał szerszy horyzont swoich zadań i potrafił pokazać, co je łączy. Praktyki w obszarze zarządzania projektami są niestety ciągle oparte na procedurach, które z jednej strony są potrzebne, ale z drugiej strony pozwalają na wycofanie się z odpowiedzialności za wyniki pracy.

Prawdziwe przywództwo w zarządzaniu projektami jest skomplikowane, wymaga zarówno czasu, jak i empatii oraz wysiłku. Opiera się na zdrowym rozsądku i bezwzględnie wymusza na zespole ciągłą elastyczność w projekcie, jak i w samej organizacji. Często wykorzystuje się metody przywództwa sytuacyjnego ${ }^{3}$. Przywództwo jest procesem wywierania pozytywnego

\footnotetext{
${ }^{3}$ Słabym punktem takiego podejścia pozostało to, że pomimo przeprowadzenia dużej liczby badań nie określono, jaki styl przewodzenia jest efektywny w prawie każdej sytuacji.
} 
Tab. 1. Charakterystyka zachowań przedsiębiorczych i kompetencji projektowych wskazywanych w wybranych modelach kompetencji

\begin{tabular}{|c|c|}
\hline Zachowania przedsiębiorcze & $\begin{array}{l}\text { Kompetencje projektowe - behawioralne } \\
\text { (wg modelu kompetencji IPMA) }\end{array}$ \\
\hline $\begin{array}{l}\text { Kryterium wg Bifulco'a } \\
\text { - } \text { sposób postrzegania otoczenia } \\
\text { - } \text { skłonność do podejmowania ryzyka } \\
\text { - } \text { organizowanie zasobów } \\
\text { - zdolność do promowania innowacji } \\
\text { - } \text { stosunek do zmian }\end{array}$ & \multirow{5}{*}{$\begin{array}{l}\text { - } \text { - } \text { zaanowództwo } \\
\text { - } \text { samokontrola } \\
\text { - } \text { asertywność } \\
\text { - relaksacja } \\
\text { - otwartość } \\
\text { - kreatywność } \\
\text { - zorientowanie na wyniki } \\
\text { - wydajność } \\
\text { - konsultowanie } \\
\text { - negocjacje } \\
\text { - konflikt i kryzys } \\
\text { - rzetelność } \\
\text { - } \text { etykartości }\end{array}$} \\
\hline $\begin{array}{l}\text { Cechy wg Bławata } \\
\text { - aktywność } \\
\text { - } \text { skłonność do ryzyka } \\
\text { - innowacyjność } \\
\text { - dynamizm } \\
\text { - } \text { samodzielność } \\
\text { - niezależność } \\
\text { - twórcze myślenie }\end{array}$ & \\
\hline $\begin{array}{l}\text { Cechy wg Gibka } \\
\text { - komunikatywność } \\
\text { - } \text { elastyczność } \\
\text { - kreatywność } \\
\text { - } \text { samodzielność } \\
\text { - dar przekonywania } \\
\text { - wyobraźnia } \\
\text { - duch konkurencyjności }\end{array}$ & \\
\hline $\begin{array}{l}\text { Cechy wg Chella } \\
\text { - poszukiwanie okazji } \\
\text { - aktywność } \\
\text { - dbanie o prestiż } \\
\text { - innowacyjność } \\
\text { - popieranie zmian }\end{array}$ & \\
\hline $\begin{array}{l}\text { Cechy wg Miltona } \\
\text { - perspektywa ujmowanych kwestii } \\
\text { - poczucie pełnienia misji } \\
\text { - } \text { przekonanie co do swoich racji } \\
\text { - doznanie potrzeby pełnej kontroli } \\
\text { - utylitaryzm } \\
\text { - akceptacja ryzyka i niepewności } \\
\text { - } \text { wykorzystanie sieci kontaktów } \\
\text { - korzystanie z wiedzy zewnętrznej } \\
\text { - } \text { posiadanie know-how }\end{array}$ & \\
\hline
\end{tabular}

Źródło: opracowanie własne na podstawie: SPM (2009) oraz K. Mrozowicz (2010: 20-21). 
wpływu (nie chodzi tu o manipulację) na członków zespołu w realizacji głównie celów projektowych. Przywódcy potrafią inspirować zarówno swoich przełożonych, jak i podwładnych. Dawno już stwierdzono, że przewodzić i kierować to nie to samo. Kierownik w projekcie zwraca uwagę na realizację strategii, na harmonogram, procedury i nadzoruje pracowników w drodze do osiągania celów. Natomiast przywódca formułuje wizję. Dobrze byłoby dla projektu, aby na jego czele stanęła osoba łącząca obie role.

Kluczami do udanego przewodzenia projektem są także: kreatywność, skuteczność i udział w odpowiedzialności za losy projektu. Kreatywność rozumiana jest jako umiejętność sprawnego poruszania się w obszarze metodyki projektu, implementowanie najlepszych rozwiązań, dojrzałość członków zespoły do odpowiedniej postawy wobec problemów, jakie projekt rozwiązuje. Skuteczność rozumiana jest jako dobór odpowiedniego narzędzia do osiągnięcia założonych efektów. Odpowiedzialność natomiast często nie jest dostrzegana lub spychana na plan dalszy. Najczęstszą jej przyczyną jest zły styl komunikacji. To w odpowiedzialności jednak należy upatrywać niewłaściwego formułowania celów i braku wsparcia członków zespołu ze strony kierowników przez niewłaściwe dopasowanie stylu przywództwa do zadań stawianych członkom zespołu.

Odpowiedzią jest tu koncepcja organizacji kompetentnej, którą można scharakteryzować jako zarządzanie przez misję. To właśnie na misji opierają się cele organizacji, nadając im odpowiedni kontekst. Dzięki temu cele stają się bardziej dynamiczne i uwzględniają wartości przyjmowane w danej organizacji. Nie ma indywidualizmu, liczy się zespół. Poza motywacją zewnętrzną - wynagrodzeniem - $\mathrm{i}$ wewnętrzną - wynikającą z zawodowego rozwoju pracownika (menedżera), pojawia się trzeci rodzaj motywacji: motywacja transcendentna. Polega ona na satysfakcji, którą menedżer odczuwa na skutek tego, że swoją pracą przyczynił się do osiągnięcia celów i misji organizacji (Cardona, Garcia-Lombardia, 2005). W tym podejściu relacja i motywacja mają głębsze podstawy niż w stylu transakcyjnym (ekonomiczne) czy transformacyjnym (zawodowe korzyści). W organizacji kompetentnej rozwój i doskonalenie przywódców wiążą się z rozwojem konkretnych ich kompetencji. Styl przewodzenia, odpowiadający organizacji kompetentnej, wymaga od menedżera, by wspierał rozwój podwładnego i sposób wykonywania przez niego pracy, co określane jest jako coaching (Baran, Kłos, 2013).

\section{Komunikacja w projekcie}

Komunikacja w ramach działań projektowych jest zdecydowanie bardziej złożona niż w ramach działalności operacyjnej. Projekty często mają charakter strategiczny, są coraz bardziej skomplikowane i złożone (pod względem organizacyjnym, zasobów czy względem technicznym). Stają się także coraz bardziej globalne, międzybranżowe i interdyscyplinarne, a ich realizacja odbywa się pod coraz większą presją kierownika projektu i innych interesariuszy (Ferraro, 2008). Należy pamiętać, iż projekty często są realizowane równolegle z działalnością operacyjną organizacji, co oznacza, że komunikacja w ramach organizacji oddziałuje na działaloność w projektach i odwrotnie.

Wielu kierowników projektów bardzo wybiórczo traktuje aspekt komunikacji, nie zwracając uwagi na jej wagę w całym procesie zarządzania projektem (w planowaniu, realizacji i zakończeniu). Złożoność projektów i ich niepowtarzalność wymagają podejścia systemowego do komunikacji. Co w konsekwencji dla kierownika projektu w zakresie komunikacji oznacza zarządzanie komunikacją? Według definicji PMI, zarządzanie komunikacją w projekcie to obszar wiedzy, który: obejmuje procesy wymagane do zapewnienia terminowego i prawidłowego opracowywania, gromadzenia, rozpowszechniania, przechowywania, wyszukiwania informacji dotyczącej projektu i ostatecznego suponowania nimi (Project Management Institute, 2009). Aby definicja ta była kompletna, należy dodać, iż potrzebna jest jeszcze umiejętność komunikacji, która odnosi się do zdolności skutecznego przekazywania pomysłów i informacji innym oraz 
do skutecznego ich przyjmowania (Griffin, 2006). Do najważniejszych umiejętności komunikacyjnych w zarządzaniu projektami zalicza się m.in. (Project Management Institute, 2009: 259):

- stosowanie techniki aktywnego słuchania,

- stosowanie dodatkowych pytań, służących zrozumieniu szczegółów,

- edukację zespołów w celu zwiększenia ich skuteczności,

- weryfikację faktów, aby potwierdzić informacje,

- zarządzanie oczekiwaniami,

- negocjowanie korzyści dla obu stron,

- rozwiązywanie konfliktów.

I tak, kolejno na etapie planowania projektu ważne jest, aby poznać wszystkie strony komunikacji, czyli nadawców i odbiorców komunikatów. Pozwoli to na przygotowanie się do skutecznej komunikacji. W etapie realizacji projektu ważna jest dystrybucja informacji, zgodnie z planem komunikacyjnym (środki przekazu, treści, czas informacji, interesariusze i ich oczekiwana). To na tym etapie kierownik monitoruje pracę zespołu, udzielając informacji zwrotnej, motywuje, zarządza zmianą. Natomiast etap zakończenia projektu wymaga głównie udokumentowania rezultatów projektu i zakończenia pracy zespołu. W związku z powyższym komunikacja nie jest tylko atrybutem kierownika projektu. Świadomością znaczenia komunikacji muszą się charakteryzować członkowie zespołu. Pozwoli ona na aktywne uczestnictwo w procesie komunikacji.

\section{Motywacja projektowa}

Myślenie o motywacji najczęściej zaczyna się przypomnieniem znanych teorii motywacji: od najbardziej powszechnej piramidy potrzeb Maslowa, przez dwuczynnikową teorię Herzberga, teorię McClellanda - dotyczącą różnic indywidualnych, po teorie słuszności i wymiany czy teorię wyznaczania celów Locke'a. Jednak aby przełożyć koncepcje te na pracę w zespole projektowym, warto przyjrzeć się samemu zespołowi. Obecnie na rynku pracy obserwujemy współpracę międzypokoleniową. Nie jest on wolna od stereotypów, które skutecznie budują mur między pokoleniami w miejscach pracy. Podczas planowania systemu motywacji w organizacji, punktem wyjściowym w projekcie musi być analiza różnorodności zespołu projektowego. Pozwoli ona na dopasowanie środków motywacji, szczególnie niefinansowych, do konkretny osób.

Charakterystycznymi środkami motywacji w przypadku zadań projektowych są: pochwała, stanowisko kierownicze w projekcie, działania integrujące zespół (wspólne wyjścia, wyjazdy), elastyczny czas pracy, możliwość godzenia życia prywatnego z życiem zawodowym, co bardzo ważne jest dla najmłodszych pokoleń obecnych na rynku pracy. Należy ustalić listę kryteriów do badania różnorodności pokoleń występujących w organizacji czy w projekcie i na podstawie analizy dopasować środki motywacji. Myślenie, iż istnieją uniwersalne zasady motywowania, które pasują do wszystkich, że zmotywowani muszą być wyłącznie członkowie zespołu projektowego, a kierownik już nie, informacja zwrotna może poczekać - powoduje popełnianie błędów w zarządzaniu zasobami ludzkimi. Parafrazując Herzberga, zmotywowany pracownik to taki, który ma wewnętrzną chęć do podjęcia określonego wysiłku (Dowling, 1978).

\section{Wnioski z badania procesu zarządzania zespołem projektowym na uczelni wyższej z zastosowaniem metodyki Pro-Five}

Opisywane badanie procesu zarządzania projektami w uczelni wyższej zorientowanej projektowo ${ }^{4}$ przeprowadzone zostało pod kątem oceny zarządzania zespołem. Miało ono na celu

\footnotetext{
${ }^{4}$ Autorzy w 2013 r. przeprowadzili badanie w wybranej warszawskiej uczelni wyższej (kryteriami wyboru organizacji do badania były: posiadanie przez uczelnię minimum czteroletniego doświadczenie w realizacji projektów; realizacja minimum 3-4 projektów w skali roku).
} 
zebranie informacji, w których obszarach zarządzania zespołem projektowym stosowane narzędzia i zachodzące procesy świadczą o dużej dojrzałości projektowej organizacji, jak również, gdzie należy dokonać zmian. Szczególną uwagę zwrócono na aspekt kreowania zachowań przedsiębiorczych w procesie zarządzania zespołem projektowym.

W badaniu wykorzystano kwestionariusz stworzony wg innowacyjnej metodyki Pro-Five (Baran, Strojny, 2013), z wyodrębnionymi pięcioma kluczowymi paramterami szczegółowymi dla jednego z wymiarów orientacji projektowej, jakim jest zarządzanie zespołem projektowym: 1. rozwój kompetencji projektowych,

2. kierownik projektu,

3. zespół projektowy,

4. komunikacja w zespole,

5. motywacja projektowa.

Zaprojektowany kwestionariusz oceny pozwolił zebrać informacje dotyczące specyficznych cech badanej uczelni, które mają istotny wpływ na realizację projektów. Mogą one jednak posłużyć także innym organizacjom, w szczególności innym uczelniom, do budowania orientacji projektowej.

Przyjęto, że: zespół projektowy koordynowany przez kompetentnego, decyzyjnego kierownika projektu, zapewniona sprawna komunikacja w zespole, stosowanie systemu szkoleń i rozwoju kwalifikacji pracowników, przy jednocześnie jasno określonej polityce motywacyjnej premiującej aktywność projektową pracowników, wpływają na skuteczne i kompleksowe zarządzanie zespołami projektowymi w procesie zarządzania projektami na uczelni. Ogólną ocenę zarządzania zespołami projektowymi badanej uczelni wyższej przedstawiono na rycinie 1 .

Z przeprowadzonego badania wynika, że zarządzanie zespołem projektowym jest jednym z kluczowych elementów zarządzania projektami w badanej uczelni. Na podstawie uzyskanych wyników, stwierdzono, że w badanej uczelni dobrze rozwinięto cechy organizacji zorientowanej projektowo, o czym świadczy wysoka sprawność zarządzania zespołem projektowym. Uczelnia ta od czterech lat realizuje co roku kilka projektów i w tym czasie wypracowała bazę wiedzy, kompetencji i procedur określających to, w jaki sposób buduje się zespół projektowy i nim zarządza. Zbiorczy wskaźnik zarządzania zespołem projektowym uzyskany przez uczel-

Ryc. 1. Ocena dojrzałości projektowej uczelni wyższej - wskaźniki zarządzania zespołem projektowym

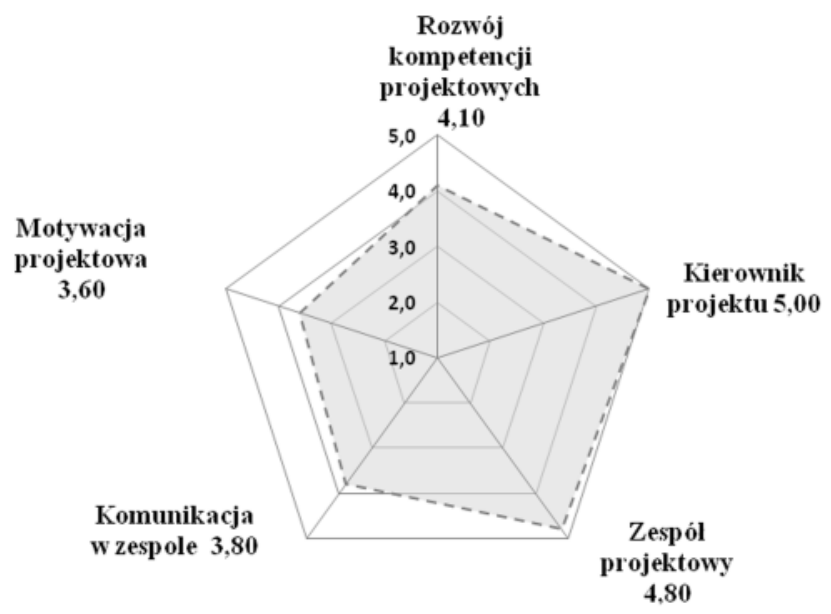

Źródło: opracowanie własne. 
nię w wyniku badania (wyliczony jako średnia z wartości szczegółowych wskaźników dla pięciu obszarów zarządzania zespołem projektowym) jest na poziomie 4,26 pkt.

Najwyżej (ryc. 2) oceniono kompetencje i możliwości rozwoju kierowników projektów (5,00 pkt), a także budowanie zespołów projektowych (4,80 pkt). Najsłabiej oceniono system i procedury motywacji projektowej (3,60 pkt) oraz komunikację w zespole (3,80 pkt). Oznacza to, że usprawnienia wymaga system komunikowania się w zespole projektowym i pomiędzy zespołami projektowymi. Konieczne są również zmiany w systemie wynagrodzeń i motywacji pracowników, jak np. wdrożenie systemu wynagrodzeń premiujących aktywność projektową pracowników uczelni.

Ryc. 2. Ocena procesu zarządzania zespołem projektowym - obszar: rozwój kompetencji projektowych

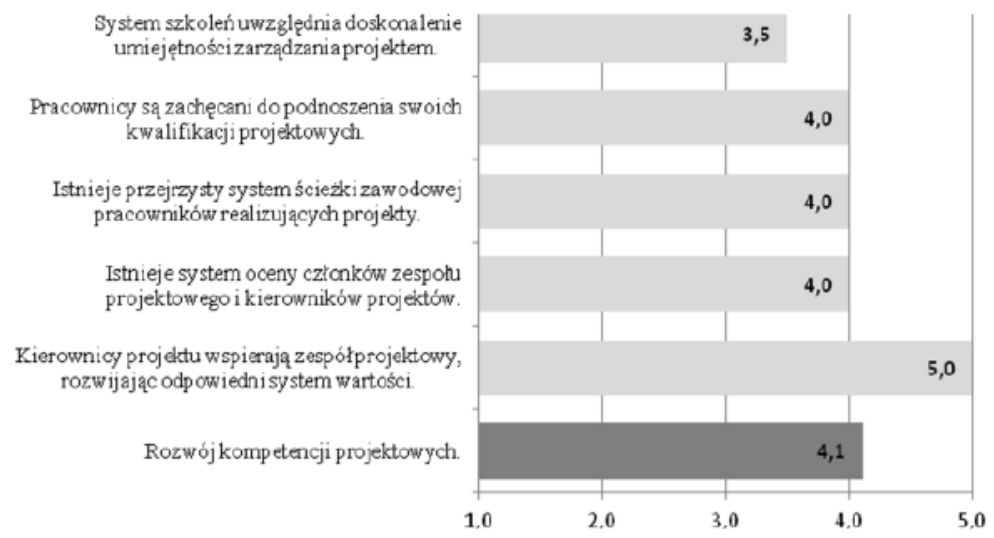

Źródło: opracowanie własne.

Zespół projektowy jest uznawany za kluczowy element procesu zarządzania projektami w organizacji, również w badanej uczelni. Najczęściej zespół projektowy tworzą osoby nieznające się wcześniej, o różnym doświadczeniu w pracy nad projektami i różnych umiejętnościach interpersonalnych, dlatego też niezmiernie ważne jest zapewnienie zespołowi możliwości rozwoju kompetencji projektowych.

Badana uczelnia dba o rozwój kompetencji projektowych przez wspieranie przez władze uczelni zespołów realizujących projekty. Kierownicy projektów wspierają swoje zespoły, rozwijając odpowiedni system wartości, pracownicy są zachęcani do podnoszenia swoich kompetencji projektowych. Istniejący system szkoleń nie ma kompleksowej oferty szkoleń doskonalących umiejętności zarządzania projektem, oferowane pracownikom pojedyncze, sporadyczne szkolenia są niewystarczające do potrzeb. Dlatego też obszar ten wymaga rozwinięcia i kompleksowego wsparcia szkoleniowego dla kadry projektowej uczelni.

Warunkiem stworzenia skutecznego zespołu projektowego jest wskazanie lidera w zespole i określenie jego obowiązków, jak również zakresu uprawnień, pełnomocnictw i odpowiedzialności. Niezależnie od tego, jak dobrze przygotowany i opracowany został projekt i jego plan realizacji, to od kompetencji zarządzającego projektem zależy jego powodzenie. Badana uczelnia stosuje system kategoryzacji kierowników projektów, określając, jakie kompetencje pozwolą na realizację danego projektu czy to rozwojowego, dydaktycznego, czy też badawczego lub innowacyjnego. Uczelnia uzyskała w wyniku badania maksymalną wartość wskaźnika w obszarze kierownik projektu (ryc. 3). 
Ryc. 3. Ocena procesu zarządzania zespołem projektowym - obszar kierownik projektu

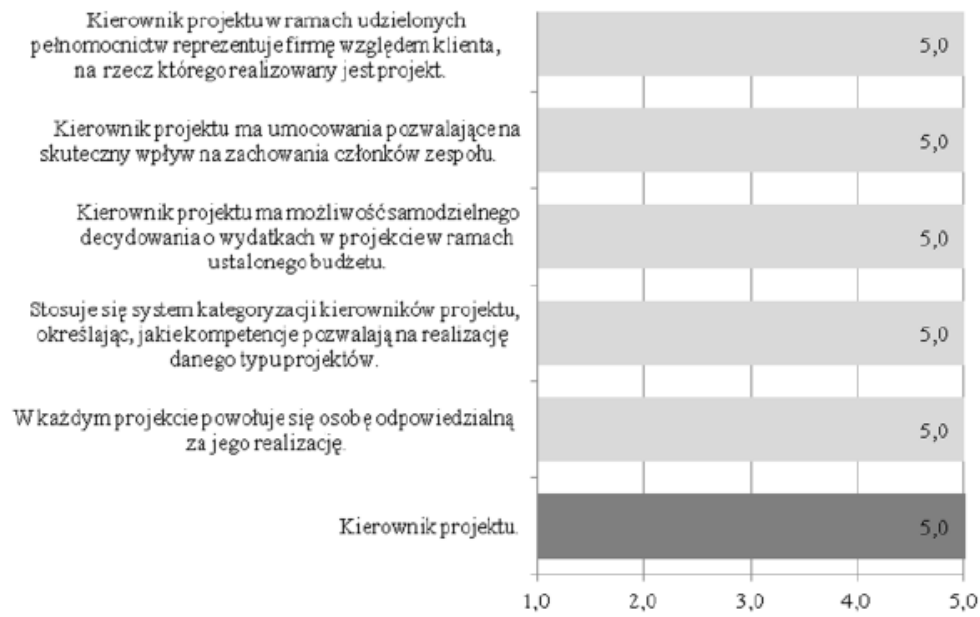

Źródło: opracowanie własne.

Precyzyjnie określone kompetencje i obowiązki poszczególnych członków zespołu projektowego sprzyjają wzrostowi zaangażowania w realizację zadań, a także podejmowaniu trafnych decyzji oraz skuteczniejszemu rozwiązywaniu problemów. Szczegółowe wskaźniki oceny tego obszaru przedstawione zostały na rycinie 4. Warto zwrócić uwagę na nieco zaniżoną ocenę w przypadku wpływu kierownika projektu na skład zespołu projektowego. Organizacja zorientowana projektowo powinna stworzyć mechanizmy pozwalające na dużą autonomię kierownika projektu. W praktyce wpływ ten często bywa ograniczany głównie na rzecz wpływów ze strony zarządu oraz innych kierowników liniowych. Dla powodzenia przedsięwzięcia projektowego równie ważny jest obszar komunikacji, a więc umiejętności komunikowania się zarówno w samym zespole projektowym, jak i komunikowania się pomiędzy zespołami poszczególnych projektów. Warunkiem skutecznej komunikacji w zespole jest określenie powiązań komunikacyjnych - relacji interpersonalnych oraz systemu komunikowania $\mathrm{w}$ ramach projektu. W badanej uczelni komunikacja w zespole projektowym obejmuje procesy, które mają zapewnić zbieranie, przechowywanie i udostępnianie informacji, przy jednoczesnej chęci pracowników dzielenia się wiedzą, wzajemnym przekazywaniu informacji (ryc. 5). Istnieje efektywny system komunikowania się w ramach i pomiędzy projektami, jednak brak jest praktycznych narzędzi w postaci szczegółowych planów komunikacji wskazujących, co komu oraz kiedy ma być przekazane.

Ważną rolę odgrywa również motywacja, która jest warunkiem niezbędnym do zapewnienia pracy w zespole w sposób efektywny i skuteczny (ryc. 6). Na szczególną uwagę zasługuje kwestia braku odpowiednio przygotowanego systemu wynagrodzeń. Jest to problem zarówno w uczelniach niepublicznych, jak i publicznych, choć w tych drugich istnieje więcej barier związanych z jego potencjalnym wdrożeniem. Konieczne jest natomiast wprowadzenie mechanizmów zarządzania przez cele oraz powiązanie stopnia ich osiągnięcia z wysokością wynagrodzenia zmiennego. W badanej organizacji problemem okazał się także element dość istotny współcześnie, a więc elastyczny czas pracy. W wielu uczelniach w części aktywności innej niż dydaktyka przyjęło się zwyczajowo akceptować elastyczny czas pracy, który szczególnie służy pracy badawczej. 
Ryc. 4. Ocena procesu zarządzania zespołem projektowym - obszar zespół projektowy

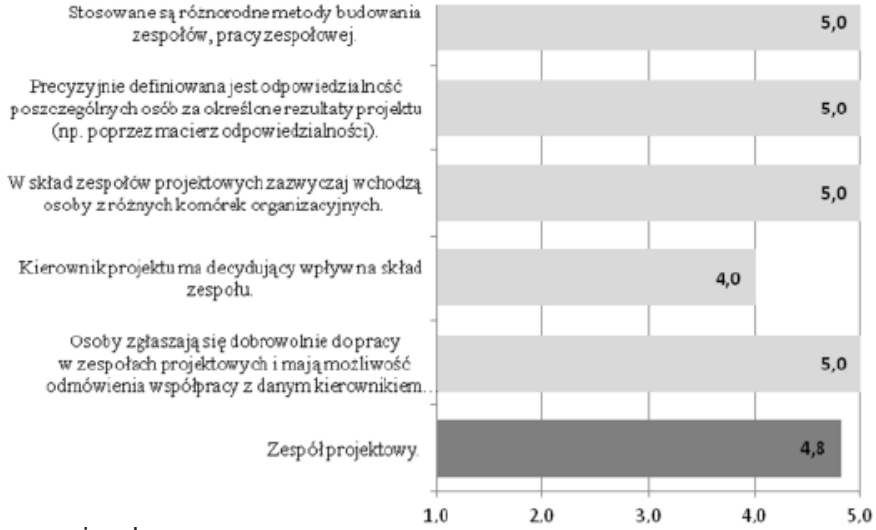

Źródło: opracowanie własne.

Ryc. 5. Ocena procesu zarządzania zespołem projektowym - obszar komunikacja w zespole

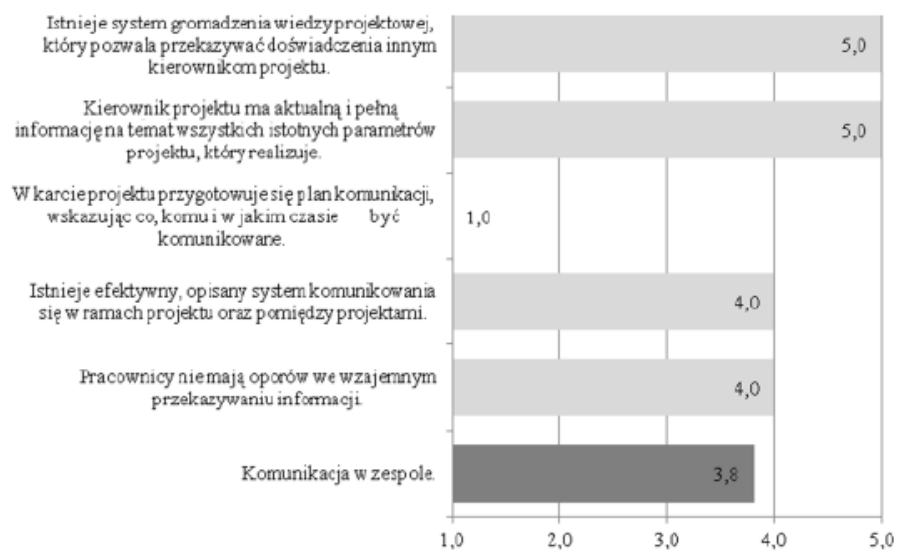

Źródło: opracowanie własne.

Ryc. 6. Ocena procesu zarządzania zespołem projektowym - obszar motywacja projektowa

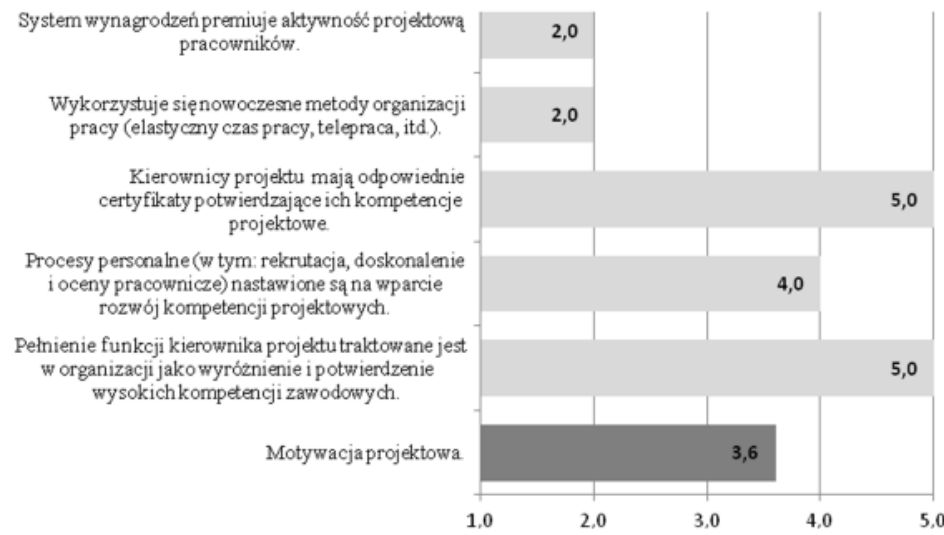

Źródło: opracowanie własne. 
Spośród badanych obszarów zarządzania zespołem projektowym na uczelni wyższej, motywacja to najsłabiej oceniony element - wymagający zmian (wskaźnik na poziomie 3,6 pkt). Chociaż na uczelni procesy personalne nastawione są na wsparcie kompetencji projektowych (procesy takie, jak: rekrutacja, ocena pracownika, doskonalenie pracowników), to jednak system wynagrodzeń nie premiuje aktywności projektowej członków zespołów projektowych, co wpływa demotywująco na pracowników projektów. Warto zwrócić uwagę na fakt, że pełnienie funkcji kierownika na uczelni traktowane jest jako wyróżnienie i potwierdzenie wysokich kompetencji projektowych, a kierownicy faktycznie mają odpowiednie certyfikaty potwierdzające ich kwalifikacje i kompetencje. Usprawnienia wymaga organizacja pracy zespołów projektowych, warto wykorzystywać nowoczesne metody pracy, np. wdrożyć elastyczny czas pracy w celu uzyskania jak największej efektywności i wydajności pracy oraz zmotywowania pracowników.

\section{Zakończenie}

Przedsiębiorczość, w tym również wewnątrzorganizacyjna (intraprzesiębiorczość), a więc także przedsiębiorczość akademicka, potrzebuje narzędzi. Współczesne organizacje często wykorzystują mniej lub bardziej systemowe rozwiązania usprawniające realizację projektów. Co więcej, coraz większa część aktywności tych organizacji ma również formułę projektową. Dlatego też należy przyjąć, że orientacja projektowa tworzy warunki do zachowań przedsiębiorczych. Szczególnie ważną cechą takiego podejścia jest zdolność do stworzenia warunków sprzyjających przyjęciu orientacji na cele i zadania.

Przedsiębiorczość to zjawisko polegające na wykorzystywaniu nadarzających się szans rynkowych. Tak właśnie powinna wyglądać aktywność współczesnych kierowników projektu, którzy w wielu wypadkach muszą być pewnego rodzaju wewnętrznymi przedsiębiorcami. Oczywiście, podobnie jak w przypadku prowadzenia własnego biznesu, również przy zarządzaniu projektami kluczowe znaczenie odgrywa świadomość odpowiedzialności za podjęte działania oraz konieczność akceptacji często wysokiego ryzyka.

Warto podkreślić, że wybór uczelni jako podmiotu badań jest nieprzypadkowy. Ograniczenia związane z tendencjami na rynku usług edukacyjnych powodują konieczność poszukiwania innych źródeł finansowania. Drugim, równie istotnym obszarem powinno więc stawać się prowadzenie badań i komercjalizacja ich wyników. W każdym z tych rodzajów działalności niezbędne są zarówno kompetencje przedsiębiorcze, jak i środowisko wewnętrzne sprzyjające realizacji projektów.

\section{Literatura \\ References}

Antoszkiewicz, J.D. (2003). Rozwijanie przedsiębiorczości - wybrane koncepcje. W: K. Piech, M. Kulikowski (red.), Przedsiębiorczość: szansą na sukces rządu, gospodarki,przedsiębiorstw, spoleczeństwa. Warszawa: Instytut Wiedzy, 11.

Baran, M., Strojny, J. (2013). Kompleksowe podejście do zarządzania projektami na przykładzie uczelni wyższej. W: E. Gołębiowska (red.), Zarządzanie w XXI wieku. Menadżer innowacyjnej organizacji, Przedsiębiorczość i Zarządzanie. tom XIV, zeszyt 12. Łódź: Wydawnictwo SAN, 247.

Baran, M. Kłos, M. (2013). Czynniki sukcesu w praktyce zarządzania miękkimi projektami unijnymi w uczelniach wyższych. W: E. Gołębiowska (red.), Zarządzanie w XXI wieku. Menadżer innowacyjnej organizacji, Przedsiębiorczość i zarządzanie. tom XIV, zeszyt 12. Łódź: Wydawnictwo SAN, 275. 
Borowski, J., Dryla, M., Kanarski, L., Rokicki, B. (2001). Człowiek w organizacji-podręczny słownik psychologii zarzadzania i dziedzin pokrewnych. Warszawa: Dom Wydawniczy Elipsa.

Boyatzis, R.E. (1982). The Competent Manager: A Model for Effective Performance. New York: John Wiley and Son.

Cardona, P., Garcia-Lombardia, P. (2005). How to develop leadership competencies. Pamplona: Eunsa - polskie wydanie (2010). Jak rozwijać kompetencje przywódcze, Kraków: Wydawnictwo M.

Dowling, W.F., Sayles, R.L. (1978). How managers motivate: The imperatives of supervision. New York: Mc Graw.

Ferraro, J. (2008). The Strategic Project Leader: Mastering Service-Based Project Leadership. New York: Auerbach Publications.

Griffin, R.W. (2006). Podstawy zarządzania organizacjami. Warszawa: PWN.

Gruszecki, T. (1994). Przedsiębiorca w teorii ekonomii. Warszawa: Cedor.

Levy-Leboyer, C. (1997). Kierowanie kompetencjami: bilanse doświadczeń zawodowych. Warszawa: Wydawnictwo Poltext.

Markowski, K. (red.). (2008). Zarządzanie zasobami ludzkimi a zdolności adaptacyjne przedsiębiorstw. Warszawa: SGH.

Mrozowicz, K. (2010). Cechy zachowań przedsiębiorczych w świetle psychologicznych badań osobowościowych. W: A. Szplit (red.), Przedsiębiorczość a rozwój regionalny Studia i Materiały. Miscellanea Oeconommicae. rok 14, Nr 1/2010. Kielce: Wydawnictwo Uniwersytetu Humanistyczno-Przyrodniczego, 20.

Oleksyn, T. (2001). Zarządzanie potencjałem pracy w organizacjach różnej wielkości. W: A. Ludwiczyński, K. Stobiński (red.), Zarządzanie strategiczne kapitałem ludzkim. Warszawa: Wydawnictwo Poltext, 16.

Piasecki, B. (1997). Przedsiębiorczość i mała firma. Teoria i praktyka. Łódź: Wydawnictwo Uniwersytetu Łódzkiego.

Project Management Institute (2009). A Guide to the Project management Body of Knowledge. 4 th edition, USA: Project Management Institute Inc.

Rostkowski, T. (2003), Zintegrowany system zarządzania kompetencjami. W: M. Juchnowicz (red.) Narzędzia i praktyka zarządzania zasobami ludzkimi. Warszawa: Poltext, 165.

Spencer, L.M., Spencer, S.M. (1993). Competence at work. New York: Wiley.

SPM (2009). Polskie wytyczne Kompetencji IPMA, wersja 3.0. Gdańsk. Pozyskano z: www.spmp.org.pl

Dałkowski, B., Staśto, L., Zalewski, M. (2009). Polskie Wytyczne Kompetencji IPMA, wersja 3.0. Gdańsk:

Wydawnictwo SPMP. Pozyskano z: www.spmp.org.pl.

Stoner, J.A.F., Freeman, R.E., Gilbert, D.R. (2001). Kierowanie. Warszawa: PWE.

Małgorzata Baran, dr, Collegium Civitas.

Ekonomistka, prorektor ds. rozwoju strategicznego Collegium Civitas, doktor nauk ekonomicznych w dziedzinie nauk o zarządzaniu. Jest autorką kilkudziesięciu publikacji naukowych oraz raportów z badań w obszarze klastrów przedsiębiorstw, zarządzania przedsiębiorstwami, wiedzy i innowacji, zarządzania projektami oraz zarządzania wiekiem. Specjalistka w dziedzinie przygotowywania projektów unijnych i zarządzania projektami. Ekspert powołany przez Ministra Rozwoju Regionalnego do oceny projektów realizowanych z funduszy unijnych, jednocześnie od $2006 \mathrm{r}$. akredytowany trener funduszy europejskich.

Malgorzata Baran, $\mathrm{PhD}$ an economist, the vice-rector for strategic development of the Collegium Civitas. The author of many scientific publications and research reports in the area of clusters, enterprise management, knowledge and innovation, project management and age management. A specialist in the field of EU funds and project management. An expert appointed by the Minister for Regional Development to assess projects from EU funds, the accredited trainer on European funds since 2006. 
Adres/Address: Collegium Civitas

Pl. Defilad 1, XII p. PKiN

00-901 Warszawa, Polska

e-mail: malgorzata.baran@collegium.edu.pl

Monika Kłos, dr, Wyższa Szkoła Biznesu w Pile.

Ekonomistka, Pełnomocnik Rektora ds. strategii WSB w Pile, doktor nauk ekonomicznych w dyscyplinie nauki o zarządzaniu. Autorka publikacji naukowych z zakresu outsourcingu, zarządzania zasobami ludzkimi (głównie z zarządzania talentami i pokoleniami), zarządzania projektami. Trener i koordynator projektów z funduszy europejskich. Członek zespołu ds. tworzenia i wdrażania projektów restrukturyzacyjnych przedsiębiorstw w Centrum Zarządzania Zmianą przy WSB w Pile.

Monika Kłos, an economist, Agent Rector for Strategy in Piła Academy of Business, a doctor of economic sciences in management science. Monika Kłos is the author of scientific publications in the field of outsourcing, human resource management (mainly in talent management and the generations), project management. A trainer and project coordinator of the European funds. A member of the team for development and implementation of corporate restructuring projects, Change Management Center at WSB in Pila.

Adres/Address: Wyższa Szkoła Biznesu w Pile

Al. Niepodległości 2

64-920 Piła, Polska

e-mail: m.klos@wsb.pila.pl

Jacek Strojny, dr, Politechnika Rzeszowska, Wydział Zarządzania, Katedra Ekonomii.

Ekonomista, doktor nauk ekonomicznych w zakresie nauk o zarządzaniu, adiunkt w Katedrze Ekonomii Wydziału Zarządzania Politechniki Rzeszowskiej, Pełnomocnik Dziekana ds. projektów rozwojowych i komercjalizacji badań. Specjalizuje się w problematyce implementacji metod i technik zarządzania w przedsiębiorstwach i jednostkach administracji publicznej, zarówno na poziomie zarządzania strategicznego, jak i operacyjnego. Jest autorem kilkudziesięciu publikacji dotyczących przedsiębiorczości i innowacji, rozwoju regionalnego i lokalnego oraz zarządzania projektami. Koordynował projekty wdrożenia innowacyjnych systemów zarządzania w kilkudziesięciu przedsiębiorstwach i samorządach. Jest także autorem strategii rozwoju lokalnego na poziomie gminnym i powiatowym.

Jacek Strojny, PhD, an assistant professor in the Department of Economics, the Faculty of Management in the Rzeszow University of Technology, The plenipotentiary of the dean for development and commercialization.

Jacek Strojny specializes in the implementation of methods and techniques in companies and public administration institutions on the strategic and operational level. The author of several dozen publications related to entrepreneurship, innovations, local and regional development as well as project management. He was a coordinator of many innovative implementation projects in companies and public institutions. He is the author of strategic documents prepared on the municipality and district level.

Adres/Address: Politechnika Rzeszowska

Wydział Zarządzania

Katedra Ekonomii

al. Powstańców Warszawy 12

35-959 Rzeszów, Polska

e-mail: jstrojny@prz.edu.pl 